\title{
Antibodies to selected pathogens in wild boar (Sus scrofa) from Catalonia (NE Spain)
}

\author{
Francesc Closa-Sebastià • Encarna Casas-Díaz • \\ Rafaela Cuenca • Santiago Lavín • \\ Gregorio Mentaberre • Ignasi Marco
}

Received: 15 October 2010 /Revised: 22 December 2010 /Accepted: 27 December 2010 / Published online: 11 January 2011

(C) Springer-Verlag 2011

\begin{abstract}
From 2004 to 2007, blood samples from 273 healthy wild boars (Sus scrofa), culled during the hunting season, were obtained in three areas of Catalonia (NE Spain): Pyrenees, Sant Llorenç del Munt i l'Obac Natural Park (SLM), and Ports de Tortosa i Beseit National Hunting Reserve (PTB). We investigated the presence of antibodies against classical swine fever virus (CSFV), African swine fever virus (ASFV), porcine vesicular disease virus (PVDV), porcine respiratory and reproductive syndrome virus (PRRSV), Aujeszky's disease virus (ADV), porcine influenza A virus (PIV), porcine circovirus type 2 (PCV2), porcine parvovirus (PPV), Mycoplasma hyopneumoniae, Erysipelothrix rhusiopathiae, Salmonella spp., and Toxoplasma gondii. Four wild boars were suspicious for CSFV, but the infection was discarded with a virus neutralization test, and infection with a border disease virus was confirmed. Negative results were obtained against ASFV and PVDV. Antibodies were detected against PRRSV (3\%), ADV (0.8\%), PIV (6.4\%), PCV2 (64.6\%), PPV (54.7\%), M. hyopneumoniae (26.6\%), E. rhusiopathiae (5.3\%), Salmonella spp. (11.3\%), and T. gondii (43.5\%). In SLM, we detected a higher seroprevalence for PIV and $M$. hyopneumoniae and a lower seroprevalence for E. rhusiopathiae than in the other two areas. In PTB, seroprevalence was higher for PPV, Salmonella spp., and PCV2. Adult wild boar displayed higher seroprevalence for PPV, PIV, and M. hyopneumoniae, whereas presence of antibodies for
\end{abstract}

Communicated by C. Gortázar

F. Closa-Sebastià $\cdot$ E. Casas-Díaz $\cdot$ R. Cuenca $\cdot$ S. Lavín ·

G. Mentaberre $\cdot$ I. Marco $(\square)$

Servei d'Ecopatologia de Fauna Salvatge (SEFaS), Departament de Medicina i Cirurgia Animals, Edifici V, Facultat de Veterinària,

Universitat Autònoma de Barcelona,

Barcelona, Spain

e-mail: Ignasi.Marco@uab.cat
Salmonella spp. was higher in juveniles compared with adults and piglets.

Keywords Seroprevalence · Spain · Sus scrofa . Wild boar

\section{Introduction}

Wild boar (Sus scrofa) is widely distributed in Europe, and it is expanding in most of the countries, including Spain (Acevedo et al. 2006). This increase may affect the circulation of pathogens between this species, domestic pigs, and humans (Artois et al. 2002; Acevedo et al. 2006). During the last years, the occurrence of wild boar disease agents in various parts of Spain has been documented (Vicente et al. 2002; Ruiz-Fons et al. 2006; Muñoz et al. 2010; Closa-Sebastià et al. 2010). However, there is little information on the presence of other important infectious diseases among wild boars in Catalonia (NE Spain). This region concentrates an important part of the Spanish pig industry and has very high densities of wild boar, which is one of the most important big game species in this area (the harvest during the 2008-2009 hunting season was approximately 29,000 animals). The objective of this study is to investigate the presence of antibodies against several pathogens in wild boar from Catalonia.

\section{Materials and methods}

From 2004 to 2007, we collected blood samples from 273 healthy wild boar hunted in three different study areas of Catalonia (NE Spain): Pyrenees (PYR; $42^{\circ} 26^{\prime}-42^{\circ} 22^{\prime} \mathrm{N}$; $1^{\circ} 27^{\prime}-2^{\circ} 26^{\prime}$ E), Sant Llorenç del Munt i l'Obac Natural Park (SLM; $41^{\circ} 39^{\prime}-41^{\circ} 42^{\prime} \mathrm{N} ; 1^{\circ} 53^{\prime}-2^{\circ} 09^{\prime} \mathrm{E}$ ), and Ports 
de Tortosa i Beseit National Hunting Reserve (PTB; $40^{\circ}$ $43^{\prime}-40^{\circ} 51^{\prime} \mathrm{N} ; 0^{\circ} 15^{\prime}-0^{\circ} 25^{\prime} \mathrm{E}$ ). Sex was determined (126 males and 147 females), as well as age class (47 piglets from 0 to 6 months, 49 juveniles from 6 months to 1 year, and 177 adults over 1 year). Blood was collected from the heart, centrifuged at $1,200 \times \mathrm{g}$ for $15 \mathrm{~min}$, serum removed, and stored at $-20^{\circ} \mathrm{C}$.

Serum samples were tested for antibodies against African swine fever virus (ASFV), classical swine fever virus (CSFV), porcine vesicular disease virus (PVDV), porcine respiratory and reproductive syndrome virus (PRRSV), Aujeszky's disease virus (ADV), porcine influenza A virus (PIV), porcine parvovirus (PPV), Mycoplasma hyopneumoniae, Erysipelothrix rhusiopathiae, and Salmonella spp. by using commercial enzyme-linked immunoassay (ELISA) tests. Antibodies against porcine circovirus type 2 (PCV2) were determined by means of an immunoperoxidase monolayer assay (Vicente et al. 2004), and Toxoplasma gondii antibodies were detected with a modified agglutination test (Dubey and Desmonts 1987).

In four CSFV-seropositive wild boars, a comparative virus neutralization test (VNT) for neutralizing antibodies against CSFV Alfort, bovine viral diarrhea virus 1 NADL, and border disease virus (BDV) strain 137/4 was performed. VNT was carried out under procedure described in the Manual of Diagnostic Tests and Vaccines for Terrestrial Animals (OIE 2004). Titres of 1:10 and higher were considered as positive. Viral replication was monitored by the immunoperoxidase monolayer assay with home-made polyclonal pestivirus-specific serum.
Variables related to study areas, sex, and age were subjected to multivariate analysis with a logistic regression procedure. Wald's test was used, and significance was assumed for $p<0.05$.

\section{Results}

Serologic results are presented in Tables 1 and 2. Antibodies were detected against PCV2 (64.6\%), PPV (56.3\%), T. gondii (43.5\%), M. hyopneumoniae (26.1\%), Salmonella spp. (11.3\%), PIV (6.4\%), E. rhusiopathiae (5.3\%), PRRSV (3\%), and ADV (0.8\%). No antibodies were detected against ASFV, PVDV, and CSFV (four wild boars were detected as CSFV positive, but a cross reaction of BDV antibodies was confirmed).

In SLM, we detected a higher seroprevalence for PIV and $M$. hyopneumoniae and a lower seroprevalence for $E$. rhusiopathiae than in the other two study areas. In PTB, seroprevalence was higher for PPV, Salmonella spp., and PCV2. Adult wild boar displayed higher seroprevalences of PPV, PIV, and M. hyopneumoniae, whereas it was higher in juveniles for Salmonella spp. when compared with adults and piglets. No differences between sexes were observed.

\section{Discussion}

Animal health surveillance is limited in wildlife but applied routinely in domestic animals. Wild boar can

Table 1 Seroprevalence (seropositive/total analyzed) against several pathogens in wild boar in the three different areas from Catalonia (NE Spain)

\begin{tabular}{lcccc}
\hline Pathogen & PYR & SLM & PTB & Total \\
\hline CSFV & $0.0 \%(0 / 74)$ & $0.0 \%(0 / 97)$ & $0.0 \%(0 / 59)$ & $0.0 \%(0 / 230)^{\mathrm{a}}$ \\
ASFV & $0.0 \%(0 / 74)$ & $0.0 \%(0 / 92)$ & $0.0 \%(0 / 55)$ & $0.0 \%(0 / 221)$ \\
PVDV & $0.0 \%(0 / 15)$ & $0.0 \%(0 / 97)$ & $0.0 \%(0 / 59)$ & $0.0 \%(0 / 171)$ \\
PRRSV & $3.9 \%(3 / 76)$ & $2.7 \%(3 / 111)$ & $2.6 \%(2 / 78)$ & $3.0 \%(8 / 265)$ \\
ADV & $0.0 \%(0 / 76)$ & $0.0 \%(0 / 100)$ & $2.6 \%(2 / 78)$ & $0.8 \%(2 / 254)$ \\
PIV & $2.6 \% \mathrm{~b}(2 / 76)$ & $10.6 \% \mathrm{a}(12 / 113)$ & $3.8 \% \mathrm{~b}(3 / 78)$ & $6.4 \%(17 / 267)$ \\
PCV2 & $36.4 \% \mathrm{a}(28 / 77)$ & $69.8 \% \mathrm{~b}(81 / 116)$ & $64.6 \% \mathrm{~b}(66 / 78)$ & $54.6 \%(175 / 271)$ \\
PPV & $42.1 \% \mathrm{a}(32 / 76)$ & $58.4 \% \mathrm{~b}(66 / 113)$ & $5.1 \% \mathrm{~b}(4 / 78)$ & $26.6 \%(71 / 267)$ \\
M. hyopneumoniae & $19.7 \% \mathrm{~b}(15 / 76)$ & $46.0 \% \mathrm{a}(52 / 113)$ & $10.3 \% \mathrm{~b}(8 / 78)$ & $5.3 \%(14 / 263)$ \\
E. rhusiopathiae & $6.6 \% \mathrm{~b}(5 / 76)$ & $0.9 \% \mathrm{a}(1 / 109)$ & $21.8 \% \mathrm{a}(17 / 78)$ & $11.3 \%(30 / 265)$ \\
Salmonella spp. & $6.6 \% \mathrm{~b}(5 / 76)$ & $7.2 \% \mathrm{~b}(8 / 111)$ & $43.6 \%(34 / 78)$ & $43.5 \%(114 / 262)$ \\
T. gondii & $45.3 \%(34 / 75)$ & $42.2 \%(46 / 109)$ & & $54.78)$ \\
\hline
\end{tabular}

Different letters indicate statistical $(p<0.05)$ differences

PYR Pyrenees, SLM Sant Llorenç del Munt i l'Obac Natural Park, PTB Ports de Tortosa i Beseit National Hunting Reserve, CSFV classical swine fever virus, $A S F V$ African swine fever virus, $P V D V$ porcine vesicular disease virus, $P R R S V$ porcine respiratory and reproductive syndrome virus, $A D V$ Aujeszky's disease virus, $P I V$ porcine influenza A virus, $P C V 2$ porcine circovirus type $2, P P V$ porcine parvovirus, $M$. hyopneumoniae Mycoplasma hyopneumoniae, E. rhusiopathiae Erysipelothrix rhusiopathiae, T. gondii Toxoplasma gondii

${ }^{\text {a }}$ Four wild boars in PYR finally confirmed as positive for border disease virus by VNT 
Table 2 Seroprevalence of antibodies against several pathogens according to three age classes: piglets (0-6 months), juveniles (6-12 months), and adults (more than 12 months)

\begin{tabular}{|c|c|c|c|c|}
\hline Pathogen & Piglets & Juveniles & Adults & Total \\
\hline CSFV & $0.0 \%(0 / 44)$ & $0.0 \%(0 / 41)$ & $0.0 \%(0 / 145)$ & $0.0 \%(0 / 230)^{\mathrm{a}}$ \\
\hline ASFV & $0.0 \%(0 / 42)$ & $0.0 \%(0 / 41)$ & $0.0 \%(0 / 138)$ & $0.0 \%(0 / 221)$ \\
\hline PVDV & $0.0 \%(0 / 21)$ & $0.0 \%(0 / 34)$ & $0.0 \%(0 / 116)$ & $0.0 \%(0 / 171)$ \\
\hline PRRSV & $4.3 \%(2 / 46)$ & $4.2 \%(2 / 48)$ & $2.3 \%(4 / 171)$ & $3.0 \%(8 / 265)$ \\
\hline ADV & $2.2 \%(1 / 46)$ & $0.0 \%(0 / 44)$ & $0.6 \%(1 / 164)$ & $0.8 \%(2 / 254)$ \\
\hline PIV & $0.0 \% \mathrm{~b}(0 / 47)$ & $0.0 \% \mathrm{~b}(0 / 48)$ & $9.9 \%$ a $(17 / 172)$ & $6.4 \%(17 / 267)$ \\
\hline PCV2 & $27.7 \%(13 / 47)$ & $58.3 \%(28 / 48)$ & $76.1 \%(134 / 176)$ & $64.2 \%(174 / 271)$ \\
\hline PPV & $17.0 \%$ a $(8 / 47)$ & $35.4 \% \mathrm{~b}(17 / 48)$ & $70.3 \%$ c $(121 / 172)$ & $54.7 \%(146 / 267)$ \\
\hline M. hyopneumoniae & $8.5 \%$ a $(4 / 47)$ & $22.9 \% \mathrm{~b}(11 / 48)$ & $32.6 \%$ b $(56 / 172)$ & $26.6 \%(71 / 267)$ \\
\hline E. rhusiopathiae & $2.1 \%(1 / 47)$ & $6.3 \%(3 / 48)$ & $6.0 \%(10 / 168)$ & $5.3 \%(14 / 263)$ \\
\hline Salmonella spp. & $4.3 \% \mathrm{~b}(2 / 47)$ & $20.8 \%$ a $(10 / 48)$ & $10.6 \%$ b $(18 / 170)$ & $11.3 \%(30 / 265)$ \\
\hline T. gondii & $48.9 \%(23 / 47)$ & $34.0 \%(16 / 47)$ & $44.6 \%(75 / 168)$ & $43.5 \%(114 / 262)$ \\
\hline
\end{tabular}

Different letters indicate statistical $(p<0.05)$ differences

$C S F V$ classical swine fever virus, ASFV African swine fever virus, $P V D V$ porcine vesicular disease virus, $P R R S V$ porcine respiratory and reproductive syndrome virus, $A D V$ Aujeszky's disease virus, $P I V$ porcine influenza A virus, $P C V 2$ porcine circovirus type $2, P P V$ porcine parvovirus, M. hyopneumoniae Mycoplasma hyopneumoniae, E. rhusiopathiae Erysipelothrix rhusiopathiae, T. gondii Toxoplasma gondii

${ }^{\mathrm{a}}$ Two piglet and two adult wild boars finally confirmed as positive for border disease virus by VNT

serve as a potential source of infectious diseases for domestic animals, and this study contributes to know the sanitary status of an area of Spain where wild boar and domestic pig share habitat.

The four wild boars detected initially as positive to antibodies against CSFV but confirmed ultimately as positive for BDV were from an area in the Pyrenees where epidemics associated to a BDV have been reported in Pyrenean chamois (Rupicapra pyrenaica; Marco et al. 2007) and where a high seroprevalence of border disease has also been reported in sheep (Alba et al. 2008). Experimental studies in pigs infected with a BDV isolated from Pyrenean chamois confirmed this seroconversion and the diagnostic challenge due to the crossreactivity of the BDV antibodies for CSFV ELISA-based tests (Cabezón et al. 2010).

The low prevalence of ADV antibodies found in the wild boars of our study suggests that this pathogen may not circulate in Catalonia. In this area, an eradication program was adapted and reinforced in 2003, leading to the almost eradication of the disease (only one positive farm in 2009). In other areas of Central and Southern Spain, seroprevalence in wild boar has been reported to be as high as $44 \%$ (Vicente et al. 2002; Ruiz-Fons et al. 2008) and outbreaks of the disease have also been described (Gortázar et al. 2002).

Antibody titres to PIV found in the wild boars of our study were low and similar to other reports in Spain (Vicente et al. 2002). Porcine influenza in wild boars is mainly density dependent in such a way that circulating rates of virus in free-ranging populations are usually low when compared to semi-captive or farmed dense populations (Ruiz-Fons et al. 2008). PCV2 seroprevalence was higher than that described previously in Hungary (20.5\%; Cságola et al. 2006), Slovenia (25\%; Toplak et al. 2004), Spain (29.7-40\%; Vicente et al. 2002; Ruiz-Fons et al. 2006), the Czech Republic (42.5\%; Sedlak et al. 2008), Belgium (35.6\%; Sanchez et al. 2001), and Germany (63.1\%; Reiner et al. 2010). Antibodies to PRRSV were higher than those previously described in free-ranging wild boars (1.3-1.7\%) (Ruiz-Fons et al. 2008). PPV seroprevalence was also high but similar to that previously described in other areas (Vicente et al. 2002; Roic et al. 2005; Ruiz-Fons et al. 2006; Vengust et al. 2006). The high infection rate in domestic pig herds, especially with PCV2 and PPV, suggests that they could be the source of infection for the wild boars (Ruiz-Fons et al. 2008). In addition, the low seroprevalence found in PYR against PPV and PCV2 supports this hypothesis because there are few domestic pig farms in this high mountain area, when compared to both the other study areas where this density is higher. But, recent investigations with non-serological studies show that wild boar is a host of pathogens like PCV2, therefore it could act as reservoir for these infections (Morandi et al. 2010, Reiner et al. 2010).

Antibodies against $M$. hyopneumoniae in the wild boar of our study were higher than those previously published in Spain (Vicente et al. 2002; Sibila et al. 2010; 0\% and $21.5 \%$, respectively), but lower to the prevalence observed in France (58\%; Marois et al. 2006). Pig farms, which usually display high prevalence of this pathogen, could be a 
reservoir for the wild boar. However, the wild boar, in which subclinical infection has been described, could also represent a potential threat for M. hyopneumoniae free farms (Sibila et al. 2010). Therefore, further research would be needed in the high seroprevalence areas to assess whether it has an impact on the wild boar populations. Seroprevalence found against E. rhusiopathiae and Salmonella spp. are similar to those previously described in other studies (Vicente et al. 2002, Vengust et al. 2006, Montagnaro et al. 2010). In PTB, a high prevalence of Salmonella spp. isolates from fecal samples was reported in the wild boar and associated with transmission from cattle (Mentaberre et al. 2009).

We found a high seroprevalence of $T$. gondii compared to other reports in wild boar in the same and in other areas of Spain (Gauss et al. 2005; Ruiz-Fons et al. 2006). However, it is similar to that described in other species in our study area, such as the red deer (Cervus elaphus; 44\%; Gauss et al. 2006) and urban cats in the Barcelona area (45\%; Gauss et al. 2003). This high seroprevalence of $T$. gondii among wild boars deserves further investigation and suggests that wild boars used for human consumption could represent a public health risk for persons handling or consuming raw or undercooked infected meat.

Sex and age are factors that can affect seroprevalence of several diseases in wild boar. Roic et al. (2005) found that adult wild boar had a higher seroprevalence to PPV $(70 \%)$ than juveniles $(31 \%)$, as observed in our study, together with PIV. Similar differences were found for $M$. hyopneumoniae, but adults and juveniles had higher seroprevalence. However, juveniles displayed higher seroprevalence of Salmonella sp. antibodies. This is similar to what is described for the domestic pig, in which antibodies are low from the first weeks of age to 1415 weeks and increase until week 30 , when these animals usually are sent to abattoir (Creus 2007). Except for Salmonella spp., adult wild boars have more probability of being exposed to pathogens and thus have higher titres of antibodies.

In conclusion, the seroprevalences to several pathogens found in our study are similar to other studies, except for PCV2, M. hyopneumoniae, and toxoplasmosis, which were higher. Source of the first two infections for the wild boar could be related to transmission from domestic pig farms. However, further studies are needed to confirm this assumption. The high rate of $T$. gondii infection of wild boar in Catalonia has important implications for public health since wild boar meat is consumed frequently.

Acknowledgments We would like to express our gratitude to the Departament de Medi Ambient and the Departament d'Agricultura, Alimentació i Acció Rural of the Generalitat de Catalunya and Diputació de Barcelona. Thanks also for the Hunting Associations.

\section{References}

Acevedo P, Escudero MA, Muñoz R, Gortázar C (2006) Factors affecting wild boar abundance across an environmental gradient in Spain. Acta Theriol 51:327-336

Alba A, Allepuz A, Serrano E, Casal J (2008) Seroprevalence and spatial distribution of maedi-visna virus and pestiviruses in Catalonia (Spain). Small Ruminant Res 78:80-86

Artois M, Depner KR, Guberti V, Hars J, Rossi S, Rutili D (2002) Classical swine fever (hog cholera) in wild boar in Europe. Rev Sci Tech OIE 21:287-303

Cabezón O, Rosell R, Velarde R, Mentaberre G, Casas-Díaz E, Lavín S, Marco I (2010) Border disease virus shedding and detection in naturally-infected Pyrenean chamois (Rupicapra pyrenaica). J Vet Diagn Investig 22:360-365

Closa-Sebastià F, Casas-Díaz E, Cuenca R, Lavín S, Mentaberre G, Marco I (2010) Brucella sp. antibodies and isolation in wild boar in NE Spain. Vet Rec 167:826-828

Creus E (2007) Mesures d'intervenció per al control de Salmonella en la cadena de producció porcina. $\mathrm{PhD}$ Thesis. Universitat Autònoma de Barcelona, Barcelona

Cságola A, Kecskeméti S, Kardos G, Kiss I, Tuboly T (2006) Genetic characterization of type 2 porcine circoviruses detected in Hungarian wild boars. Arch Virol 151:495-507

Dubey JP, Desmonts G (1987) Serological responses of equids fed Toxoplasma gondii oocysts. Equine Vet J 19:337-339

Gauss CBL, Almería S, Ortuño A, García F, Dubey JP (2003) Seroprevalence of Toxoplasma gondii antibodies in domestic cats from Barcelona, Spain. J Parasitol 89:1067-1068

Gauss CBL, Dubey JP, Vidal D, Ruiz F, Vicente J, Marco I, Lavín S, Gortázar C, Almería S (2005) Seroprevalence of Toxoplasma gondii in wild pigs (Sus scrofa) from Spain. Vet Parasitol 131:151-156

Gauss CBL, Dubey JP, Vidal D, Cabezón O, Ruiz-Fons F, Vicente J, Marco I, Lavín S, Gortázar C, Almería S (2006) Prevalence of Toxoplasma gondii antibodies in red deer (Cervus elaphus) and other wild ruminants from Spain. Vet Parasitol 136:193-200

Gortázar C, Vicente J, Fierro Y, León L, Cubero MJ, González M (2002) Natural Aujeszky's disease in a Spanish wild boar population. Ann NY Acad Sci 969:210-212

Marco I, López-Olvera JR, Rosell R, Vidal E, Hurtado A, Juste R, Pumarola M, Lavín S (2007) Severe outbreak of disease in the Southern chamois (Rupicapra pyrenaica) associated with border disease virus infection. Vet Microbiol 120:33-41

Marois C, Tocqueville V, Le Potier MF, Hars J, Kobisch M (2006) Detection of Mycoplasma hyopneumoniae in French Wild Boars. In: 19th International Pig Veterinary Society, Copenghaguen, Denmark, p. 213

Mentaberre G, Lavín S, Marco I, Serrano E, Allepuz A, Porrero MC, García M, Gómez S, Domínguez L (2009) Transmisión de Salmonella entre fauna salvaje y ganado vacuno en la Reserva de Caza de Ports de Tortosa i Beseit (NE, España). In: Resumés des 27èmes Rencontres du GEEFSM. Col du Marchairuz, Suisse. June 11-14

Montagnaro S, Sasso S, De Martino L, Longo M, Iovane V, Ghiurmino G, Pisanelli G, Nava D, Baldi L, Pagnini U (2010) Prevalence of antibodies to selected viral and bacterial pathogens in wild boar (Sus scrofa) in Campania Region, Italy. J Wildl Dis 46:316-319

Morandi F, Verin R, Sarli G, Canetti N, Scacco M, Panaresse S, Poli A (2010) Porcine circovirus type 2 (PCV2) antigen localisation and post-weaning multisystemic wasting syndrome (PMWS) in freeranging wild boar (Sus scrofa ssp scrofa) in Italy. Eur J Wildl Res 56:717-724

Muñoz PM, Boadella M, Arnal M, de Miguel MJ, Revilla M, Martínez D, Vicente J, Acevedo P, Oleaga A, Ruiz-Fons F, Marín 
CM, Prieto JM, de la Fuente J, Barral M, Barberán M, Fernández de Luco D, Blasco JM, Gortázar C (2010) Spatial distribution and risk factors of Brucellosis in Iberian wild ungulates. BMC Infect Dis 10:46-60

OIE, 2004. Border disease. In: Manual of diagnostic tests and vaccines for terrestrial animals. Available at http://www.oie.int/ eng/normes/mmanual/A 00131.htm

Reiner G, Bronnert B, Hohloch C, Fresen C, Haack I, Willems H, Reinacher M (2010) Qualitative and quantitative distribution of PCV2 in wild boars and domestic pigs in Germany. Vet Microbiol 145:1-8

Roic B, Cajavec S, Toncic J, Madic J, Lipej Z, Jemersic L, Lojkic M, Mihaljevic Z, Cac Z, Sostaric B (2005) Prevalence of antibodies to porcine parvovirus in wild boars (Sus scrofa) in Croatia. J Wildl Dis 41:796-799

Ruiz-Fons F, Segalés J, Gortázar C (2008) A review of viral diseases of the European wild boar: effects of population dynamics and reservoir rôle. Vet J 176:158-169

Ruiz-Fons F, Vicente J, Vidal D, Höfle U, Villanúa D, Gauss C, Segalés J, Almería S, Montoro VI, Gortázar C (2006) Seroprevalence of six reproductive pathogens in European wild boar (Sus scrofa) from Spain: the effect on wild boar female reproductive performance. Theriogenology 65:731-743

Sanchez R, Nauwynck H, Pensaert M (2001) Serological survey of porcine circovirus 2 antibodies in domestic and feral pig populations in Belgium. Proc. ssDNA viruses of plants, birds, pigs and primates. St.Malo (France), 122

Sedlak K, Barbova E, Machova J (2008) Antibodies to selected viral disease agents in wild boars from the Czech Republic. J Wildl Dis 44:777-780

Sibila M, Mentaberre G, Boadella M, Huerta E, Casas-Díaz E, Vicente J, Gortázar C, Marco I, Lavín S, Segalés J (2010) Serological, pathological and polymerase chain reaction studies on Mycoplasma hyopneumoniae infection in the wild boar. Vet Microbiol 144:214-218

Toplak I, Grom J, Hostnik P, Barlič-Maganja D (2004) Phylogenetic analysis of type 2 porcine circoviruses identified in wild boar in Slovenia. Vet Rec 155:178-180

Vengust G, Valencak Z, Bidovec A (2006) A serological survey of selected pathogens in wild boar in Slovenia. J Vet Med B 53:2427

Vicente J, León-Vizcaíno L, Gortázar C, Cubero MJ, González M, Martín-Atance P (2002) Antibodies to selected viral and bacterial pathogens in European wild boars from Southcentral Spain. J Wildl Dis 38:649-652

Vicente J, Segalés J, Höfle U, Balasch M, Plana-Duran J, Domingo M, Gortázar C (2004) Epidemiological study on porcine circovirus type 2 (PCV2) infection in the European wild boar (Sus scrofa). Vet Res 35:243-253 